\title{
On the Basic Categories of Facilitative Pedagogy
}

\section{Sobre de las categorías básicas de la pedagogía facilitadora}

\author{
Avdeeva Irina
}

Sevastopol State University, Sevastopol, Russian Federation

ORCID ID: https://orcid.org/0000-0002-4214-8957

\section{Hrabrova Valeria}

Sevastopol State University, Sevastopol, Russian Federation

ORCID ID: https://orcid.org/0000-0003-4215-8749

\section{Adonina Larisa}

Sevastopol State University, Sevastopol, Russian Federation

ORCID ID: https://orcid.org/0000-0002-1322-4244

\section{Shutova Olga}

Sevastopol State University, Sevastopol, Russian Federation

ORCID ID: https://orcid.org/0000-0002-8417-2920

\section{Rusnakova Elizaveta}

Sevastopol State University, Sevastopol, Russian Federation

ORCID ID: https://orcid.org/0000-0001-8269-6811

Received 07-07-20 Revised 07-25-20 Accepted 09-13-20 On line 09-30-20

*Correspondence

Email: avdeeva_ir@bk.ru
Cite as:

Avdeeva, I., Hrabrova, V., Adonina, L., Shutova, O., \& Rusnakova, E. (2020). On the Basic Categories of Facilitative Pedagogy. Propósitos y Representaciones, 8 (SPE3), e726. Doi: http://dx.doi.org/10.20511/pyr2020.v8nSPE3.726 


\section{Summary}

A key characteristic of a learner-centered educational process is its realization as a subject-tosubject interaction between participants. At present, a view that the goal of the pedagogical process is to create conditions for the development of a creative and moral personality, independent in cognitive and practical activities, free to choose a professional, social, family career can be considered customary. A rounded actualized personality is, first of all, the subject of human relations and conscious self-work. That is, this is a person who has a conscious and stable system of relations to themselves and the world, who is able to realize the motives of their activities, set a goal, and independently regulate their own actions to achieve it. A teacher positions oneself as a facilitator in this interaction, and a firm promotion of the student's ability to be the subject of one's own relationships, behavior, becomes the main principle of professional work of both each teacher taken separately and the teaching staff as a whole.

Keywords: Facilitative Pedagogy, facilitative pedagogy, creativity of self-actualization.

\section{Resumen}

La característica clave del proceso del desarrollo personal educativo es su implementación como una interacción de sujeto a sujeto entre los participantes. En la actualidad se puede considerar la disposición generalmente aceptada, de que el objetivo del proceso pedagógico es la creación de condiciones para el desarrollo de la personalidad creativa y moral, independiente en cognitivo y actividad práctica, libre en elección de una carrera profesional, social y familiar. La personalidad desarrollada y actualizada es, ante todo, un sujeto de relaciones humanas y auto actividad consciente. Es decir, es una persona que posee un sistema consciente y sostenible de relaciones con ellos mismos y el mundo, la cual es capaz de comprender los motivos de su actividad, poner una meta y por sí mismo regular sus acciones para su logro. El pedagogo ocupa en esta interacción la posición de facilitador, y la asistencia constante al desarrollo de la capacidad del alumno para ser sujeto de sus propias relaciones, el comportamiento se vuelve un principio fundamental de la actividad profesional, como individuo, profesor y en general los de colectivos pedagógicos.

Palabras clave: pedagogía facilitadora, creatividad de autorrealización, libertad personal.

\section{Introduction}

In modern theory and practice of education, the main maxims of a learner-centered, subjectoriented educational paradigm are concentrated in a new promising direction of pedagogical activity - facilitative pedagogy. The initial concept of facilitative pedagogy is the concept of vocational education, developed by G.M. Kodzhaspirova (2009), O.S. Gazman (2000), V.A. Slastenin, L.S. Podymova (1997), A.I. Zakharov (2020) and others.

The next stage in the development of facilitative pedagogy is the concept of educational space. V.I. Panov, T.Iu. Gerasimova (2006) and others were engaged in the design and modeling of the educational environment.

Representatives of contextual learning (Kh.A. Bakshaeva, A.A. Verbitskii (2006), and others) made a significant contribution to the development of facilitative pedagogy. The pedagogical facilitation was also based on the works by V.I. Andreev (1988), L.N. Borisova (1999), I.V. Vachkov, S.D. Deriabo (2000), A.K. Markova (1996), showing the results of the study of professional reflection and reflective learning.

Humanistic psychology, represented by the provisions of I.N. Avdeyeva (2013), O.S. Gazman (2000), O.I. Dimova (2002), S.Ia. Romashina, A.A. Maier (2010), A. Maslow (2002), P.B. Ovcharova (2007) and others gave the greatest impetus for the development of concepts of pedagogical facilitation. 
It is facilitative pedagogy that relies on the principles and technologies of the subject-tosubject interaction of the participants in the educational process, enables teachers to exert a psychologically appropriate developing influence on learners, ensuring the formation of such qualities as agency, capacity for self-actualizing and other psychosocial characteristics associated with the above (Avdeyeva, 2013). In Russian psychological and pedagogical studies, the pedagogical focus was considered within the activity approach (A.N. Grigorieva (2004), A.K. Markova (1996), E.I. Scheblanova (2018), and others). However, these studies almost neglected the facilitative orientation. A significant contribution to the development of facilitative pedagogy was made by S.Ia. Romashina, A.A. Maier (2010), A. Maslow (2002), C. Rogers, J. Freiberg (2002), S.G. Stepanov (2002).

I.V. Zhizhina (2000), L.N. Kulikova (2001), P.B. Ovcharova (2007), V.I. Panov, T.Iu. Gerasimova (2006), S.Ia. Romashina, A.A. Maier, (2010), A.I. Savenkov (2008) and others considered pedagogical as a special psychological and pedagogical process, and analyzed the conditions and ways of its formation.

This article deals with the description of the fundamental categories of facilitative pedagogy, on the basis of which appropriate educational technologies, organizational algorithms, models and training programs for teachers are developed.

The benchmark of facilitative pedagogy in Russian universities is the idea of the orientation of the personality. One of the first to come to the need to study was A.I. Savenkov. He believed that the orientation of the personality is its system-forming trait (Savenkov, 2008). According to M.V. Clarin, motives of activity are determined by its tasks and goals (Clarin, 2020).

Further study of the orientation of the personality is associated with the study of the structure of its motivational sphere (Matyunin, 1994). To characterize the orientation of the personality, V.N. Miasishchev uses the concept of "dominant attitude" (Grigorieva, 2004). The

Agency is a holistic characteristic of an individual's actions, found in their activity and behavior, which allows imagining an individual not as an impassive agent (this is how the category "subject" is used in terms of philosophical analysis), but as a "biased screenwriter of their actions (at higher levels the development of even the director), which is inherent in certain preferences, and ideological positions, and the purposefulness of the changer" (Osnitsky, 1996, p. 5-6). Agency is manifested in an individual's activity, first of all, in those types of the life's activity in which he/she "is free (and reveals his/her will) to determine for oneself both the measure of subject involvement and the measure of his/her own creativity when achieving the goals formulated for oneself" (Osnitsky, 1996, p.7).

The development of subject activity skills is possible only in the process of individual acquisition and consolidation of personal experience of such activity. The experience of subject activity is a necessary condition for the formation of a creative personality. Therefore, the experience of subject activity should be an obligatory requirement of the educational process aimed at the formation of such a person.

The connection of agency and creativity in terms of goals of a personality-oriented education requires special definitions.

The theoretical analysis showed that facilitative pedagogy is at the stage of its formation. Many theoretical aspects require concretization and deeper comprehensive analysis. 


\section{Creativity of self-actualization}

When we speak of the development of a creative personality, we mean the development of not only and not so much the knack for "special creativity" (as the creativity associated with the creation of a new product), but rather the development of the capacity for "creativity of selfactualization" (A. Maslow), which manifests itself in various aspects of life (Maslow 2002, p.117). Creativity of self-actualization is an individual's tendency to find imaginative (fresh, original, inventive) ways to everything that they do, first of all, in those areas of life that are personally meaningful, accessible and desirable for them. The result of creativity of selfactualization can be a real work, and new relationships, and a new position, and an independent balanced decision (Maslow, 2002).

Creativity of self-actualization is a subject category. Only a human who is able to take independent (fearless and spontaneous - according to A. Maslow (2002) and conscious (subjectoriented) actions, formulate and stand up for their ideas, purposefully and persistently realize them, reveals his/her true form as a creative personality. It is that person who has an impulse for creative action (independently chosen life action) is realized not only at the level of "I want!", but also at the levels of "I can!" and "I do! (I act precisely this way!)."

And this "I can!" means: firstly, "I have the means" of creative mental activity (I know special techniques), and, secondly, "I have the qualities of inner freedom" that allow for the creative (new, independent, spontaneous, confident, open, conscious, bold - V.I. Andreyev (1988), D.B. Bogoyavlenskaya (1999) V.N. Druzhinin (2019), A.M. Luk (1978), A. Maslow (2002), V.A. Molyako (1983), Z. Petrasinsky (1988), C. Rogers (2002) others) thinking and action. "I act precisely this way" means: I have a stable propensity to do and act in accordance with my own choice, I strive to actualize my inner potential.

Speaking of "inner" intentional readiness for self-actualization, we mean the ability for free personal self-realization, for "freedom of creative expression" (N.A. Berdyaev, 1993). Leading humanistic psychologists and teachers, such as G.A. Ball (2011), M.M. Bakhtin (1986), D.A. Leontiev (2011), V.A. Molyako (1983), A. Maslow (2002), C. Rogers, F. Perls, P. Goodman and others, have been writing about such freedom as the most important condition for the formation of a moral and creative personality.

According to N.A. Berdyaev, personal freedom is one of the most important conditions for the implementation of specifically human existence, offering possibilities for creativity. The concept of freedom "revives", triumphs in non-deterministic creativity when a free impulse to novelty rushes from the depths of the human "Self". In creativity, an individual feels he/she is a subject. And it is the subject that has the capacity for creativity. "... The initial component that defines the subject as an individual... (is) the individual's ability to create and, accordingly, to realize this ability" (Bystrova, 2002, p.41-42).

It is the capacity for creativity of self-actualization that makes up the basic content of the category of "moral and creative personality". Therefore, the creation of conditions for the becoming of a personality as an agent capable of creative self-actualization is the main task of a personality-oriented, learner-centered education (Ball, 1997, p.9).

V.I. Andreyev (1988), D.B. Bogoyavlenskaya (1999), V.M. Druzhinin (2019), A. Maslow (2002), V.A. Molyako (1983), A. Olah (1968), Z. Petrasinsky (1988), Y.O. Ponomarev (1990), C. Rogers (2002) and others scholars single out the qualities inherent in a creative self-actualized personality: courage, inner directedness, critical stance towards the usual, originality, inner openness, sensitivity to everything new and unusual, high degree of tolerance to uncertain situations, initiative, intensive search motivation, unlimited spontaneity, expressiveness, intellectual flexibility. It is these qualities that facilitate a personal readiness to perceive, 
assimilate and actively use the means of creative mental activity, confidently and carefully build their own behavioral strategies in various accessible areas of life. Persistence (the stability of manifestation in various situations of life activity) of the personality traits mentioned above allows for the judgement of the level of development of a person's capacity for the self-actualization.

In general, it can be noted that the essential characteristics of a human who is capable of creative self-actualization are constant and confident readiness of an individual for active search activity, for making independent decisions in intricate or complicated situations, positive cognitive and behavioral spontaneity. Like any personality growth, such qualities are fully formed within the framework of a leading activity under the influence of the corresponding social development situation.

Social situation of development is a place that an individual occupies in the system of relationships (first and foremost, social) with the environment. At the same time, initiating influences of the environment on the personality that develops are exerted via a social situation of development. The system of social relationships becomes a development situation when its demands are accepted by the recipients of these demands as relevant, necessary for them at the moment of life, and also when in the process of communication and interaction with the translators of the demands of the social situation of development a person has the opportunity to perceive and successfully test means (methods) of adequate answers to these requirements. The content and quality of new mental formations - knowledge, skills, abilities of emotional and behavioral response, various capacities, depend on the content and nature of the social relationships between the recipient of the social development situation and the carriers of sociocultural requirements.

The analysis of works dealing with the study of psychological patterns of development of creative abilities and creative personality (V.I. Andreyev (1988), D.B. Bogoyavlenskaya (1999), V.M. Druzhinin (2019), L.B. Ermolayeva-Tomina (1990), V.V. Klimenko (2001), E.I. Kulchitska (2003), V.A. Molyako (1983), A.M. Matyushkin (1989) and others), the role of humanistic, learner-oriented education in actualizing the creative potential of a person (S.A. Amonashvili (1990), G.A. Ball (2011), O.S. Gazman (2000), M.V. Klarin (2002), A. Maslow (2002), C. Rogers (2002) and others) allows highlighting the most important features of pedagogical process as a social situation of development, stimulating the development of the creative personality of students, namely:

- pedagogical process (organized as a system of diverse social relationships) is aimed at initiating the subject activity of the participants;

- educational interaction provides constant positive support of the independent search activity of children, their spontaneous creative manifestations;

- pedagogical process is implemented as a subject-to-subject interaction between the participants;

- mastering the methods of creative mental activity is, first of all, a means of forming subjectivity as the most important attribute of a student's position;

- in the educational interaction, a teacher organizes the system of communication and informational relationships between the participants of the study which in an interactive way stimulates the reflection of the personal experience of the participants and encourages them to independently search for and test new ways to solve existing tasks, to formulate personal motives for learning.

"When students are allowed to face real problems; when a teacher makes resources, both human and technical, psychologically accessible for students; when a teacher in their relations with students appears to be a real person who has a sense of acceptance and empathy about them - then a stimulative teachings takes place" (Osnitsky, 1996). Stimulative subject activity. 
However, a student in our schools mainly plays an object role. They must be taught, developed, educated. The subject influences of teachers are directed at them. The possibilities of being a subject of educational activity for a modern pupil are quite restricted. School has only formed an individuality, but not a personality, as a conscious organizer of one's own and surrounding life, as a person has the capacity for creativity of self-actualization.

In relation to the content-dynamic aspect, the social situation of development is realized in leading activities. It is known that the essential characteristic of a leading activity is its personal relevance to humans. Undoubtedly, the educational activity for the vast majority of students is relevant, and certain new formations in the process of school work appear. But the fact is also proved that the personal relevance of educational activities is negative for most schoolchildren. In particular, the researchers in the field of the problems of child development note that fears of various etiologies accompany the school life of most students (A.I. Zakharov (2020) and other). And anxiety, fears play a significant role in the formation of defenses that impede selfactualization and inhibit the realization of a person's creative potential (A.I. Zakharov (2020), and others).

The most typical among school fears are: fear of failure in work, fear of being incurred ridicule (N. Karpenko, 1997). A.I. Zakharov, who has been studying the issue of school fears for many years, singles out the fear of the teacher as the most common among schoolchildren. These fears become powerful regulators of behavioral and intellectual activity, an obstacle to the development of creative abilities and personality.

The key role in the emergence and fixation of the phobic states of schoolchildren in the formation of unproductive defense mechanisms is played by teachers (I.V. Dobrogayeva (2020), O.I. Zakharov (2020), and others). Moreover, frustrated agency acts as a mechanism for the emergence of most school fears, anxiety, unproductive psychological defenses, as well as many other psychological limitations of creative self-realization (D.B. Bogoyavlenskaya (1999), V.A. Slastenin (2019)). The traditional style of teaching and educational influences does not accept, and often dampens the existing manifestations of the subject activity of pupils, more so that in their initial manifestations, developing agency has the features of uncontrolled spontaneity, impulsivity, unstable (in the language of school bureaucracy - "inadequate") emotionality, low self-regulation.

Unfortunately, even the already formed high abilities (for example, of students of new types of schools, of gifted children) for intellectual creativity are not a sufficient condition for full personal self-realization (E.I. Shcheblanova (2018), A.I. Savenkov (2008), etc.). The scholars involved in the problems of the psychology of creative abilities and creative talents write about the destructive impact on the productivity of training of such characteristics of gifted students as: fear of failure, high anxiety, instability of thinking during stress, external attribution, negative self-feeling (A.M. Matyushkin (2018), V.A. Orlov (2017), A.I. Savenkov (2008) and others), and point out the need for serious organizational and corrective-propaedeutic work to prevent these states within school environment.

These data indicate that in the conditions of a typical - learning-forming - paradigm of pedagogical interaction, children learn in the mode of adaptation, frustration of subject activity. The vast majority of them has the motivation for learning to be of forced (deficient) character. Against this background, one cannot say much for the systemic development of subject experience and agency.

The optimal conditions for the development of any abilities is their occurrence in response to the demands of the social situation of development in the process to be leading, as well as the possibility of using these abilities as a means of implementing a leading activity. For the ability to self-actualize creativity, such an activity is a search, transformative activity that is free of compulsory motivation (D.B. Bogoyavlenskaya (1999), V.N. Druzhinin (2019), and others). 
This standing requires a different approach to the consideration of educational activity ${ }^{1}$, in which a creative personality of a student should develop. Firstly, it should be an activity that is "devoid of forced motivation". Such activity appears if a joint educational activity initiates a spontaneous motivation of a child to express themselves creatively and allows for the positive support to selfactualize. This refers to multichannel external support coming from relevant carriers of the requirements of the social development situation. Such joint activity within the environment of actualizing supportive interaction facilitates the emergence of the positive relevance of educational activities and, accordingly, the transfer of its need-motivational attributes from deficient to existential level, consequently being a favorable condition for the development of new personality formations of the self-actualizing group.

One more factor of the positive actuality of educational activities is the opportunity for the student to be and feel a full-fledged subject of this activity. That is, joint educational activity should stimulate manifestations of agency and be based on them. Proceeding from the understanding of agency as a "meaningful and effective characteristic of conscious activity associated with the search and definition of tasks2, the search for the means of their successful solution and the search for the means of coordinating their own aspirations with the efforts of other people" (Osnitsky, 1996, p. 10-11.), as well as "the ability not only to joint but also disjoint definition of their tasks, separated from others" (Osnitsky, 1996, p.9), one can conclude that in a positively relevant educational interaction a child should be provided a possibility of independent ("separated from others") choice of the ways of response, the variants of these ways should be presented, as well as the possibility of their reliable (painless) testing.

Such a joint educational activity facilitates the formation of educational activity as developing the capacity for creative self-actualization.

Thus, the joint educational activity should provide the student's subjective position regarding the demands of the social situation of development, as well as positive external support for his/her experience of creative self-actualization (a person should be sufficiently mature to have an autonomous internal support of his/her own creativeness). Such activity naturally acquires the character of subject-to-subject interaction. In this interaction, the teacher and students act as principally equal partners in learning. Equality means the equal value of the individual subjective position of all participants in the educational process. In the context of the development of the capacity for creativity of self-actualization, learning acts as an actualizing subject-to-subject interaction, which is primarily aimed at initiating and consolidating the widest possible experience of the subjective behavior of participants.

At the same time, the position of the teacher changes fundamentally. In the traditional educational process, the teacher plays the role of a "filter", which pumps through itself and doses educational information, imposing the means of working with it and the psychological forms of its assimilation. In the actualizing subject-to-subject interaction, the teacher takes the position of an assistant in work, a consultant of one of many information sources. He undertakes the role of an organizer of a system of stimulating relationships (social development situation) between the subjects of educational activity, a "collector" of general semantic field from which examples of solution of the problems are drawn (in the process of individual reflective choice).

We call this interaction facilitative (English Facilitate - to help, to make an action or process easier, to further). This is an educational interaction, as a result of which the subject position of a student and a teacher is formed, strengthened and socially defined, their personal

\footnotetext{
${ }^{1}$ In this context we differentiate between individual (hereinafter - "educational activity") and joint educational activity, which is determinative for the first one, its external condition.

${ }^{2}$ Definition of their "importance for oneself", making a personal sense of the tasks
} 
growth takes place, and the internal reserves of mental development open out. It is essential that the purpose and content of facilitative interaction is the encouragement of independent personal development, and not the purposeful actions of the teacher towards certain new formations.

Facilitative interaction involves the interaction of not only students with a teacher, but also students among themselves. Learning within facilitative interaction provides for the organization of the educational process in such a way that almost all of its participants are involved in the cognitive process, have the ability to understand and reflect on what they know and think. The subject activity of students in the process of cognition and assimilation of educational material means that everyone makes a special individual contribution to it, there is an exchange of knowledge, ideas, ways of cognitive activity. Moreover, this happens in an atmosphere of goodwill and mutual support, which not only allows accumulating new knowledge, but also develops the very cognitive activity, transfers it to a higher - personally motivated - level. In the conditions of facilitative interaction, students receive and consolidate the positive experience of subject behavior and free creative self-expression. The teacher, as a facilitator, incites students to participation, provides an interpretative and semantic basis for the educational dialogue. The main characteristics of this dialogue are pluralism, subjects' involvement, context, etc.

The psychological meaning (appropriateness) of just such an interaction in organizing work to facilitate the development of a creative personality is presented in works by A. Maslow (2002) and other prominent representatives of humanistic psychology.

The importance of facilitation-oriented pedagogical actions is constantly emphasized by Russian scholars. Although the term "facilitation" and its derivatives are not always used, the authors, speaking of the "developing actions" of the teacher, mean exactly facilitative influences as actions that ensure the actualization of self-development potentials against the backdrop of different social practice.

In the works of these authors, we find targets for the development of psychological and pedagogical technologies of facilitating the development of creative abilities, and more precisely - the development of the ability of creative self-actualization.

Thus, A. Maslow's (2002) informal description of the "moments of self-actualization", which to a certain extent reveals the mechanism of formation of the ability to self-actualizing (first of all, through the accumulation of positive experience of living these moments), allows for the identification of the target priorities of facilitative pedagogical actions aimed at developing assistance to a student in their personal growth (see Table 1). 
Table 1: Milestones of Facilitative Pedagogical Actions in Accordance with the Characteristic of the "Moments of Self-Actualization" by A. Maslow (2002)

\begin{tabular}{|l|l|}
\hline \multicolumn{1}{|c|}{ Self-Actualization Moments } & $\begin{array}{l}\text { Milestones of Facilitating Actions of a } \\
\text { Teacher }\end{array}$ \\
\hline $\begin{array}{l}\text { Complete living emotional experience with full } \\
\text { concentration and full absorption. Going beyond the } \\
\text { restrictions concerning a pose, shyness, timidity. } \\
\text { Self-expression. Selflessness. }\end{array}$ & $\begin{array}{l}\text { Providing the conditions for the emergence } \\
\text { and fixation in the "positive personal } \\
\text { experience" of a student of such experiences. }\end{array}$ \\
\hline $\begin{array}{l}\text { The decision in favor of personal growth at every } \\
\text { moment of choice. Choosing the safe means staying } \\
\text { with the known and familiar. Choosing growth } \\
\text { means opening oneself up to a new unexpected } \\
\text { experience. }\end{array}$ & $\begin{array}{l}\text { Creating an atmosphere of social acceptance } \\
\text { (approval of an independent value choice. }\end{array}$ \\
\hline $\begin{array}{l}\text { Realization of the self. The self exists, and "listening } \\
\text { to the inner voice" means making it self-actualize. }\end{array}$ & $\begin{array}{l}\text { Activization of manifestations of the } \\
\text { student's individuality, creation of } \\
\text { conditions for the accumulation of positive } \\
\text { Honesty and assuming responsibility. } \\
\text { coperience of independent decisions, for } \\
\text { conscious self-acceptance. }\end{array}$ \\
\hline $\begin{array}{l}\text { Constant development of our abilities, using them to } \\
\text { do well what we want to do. A self-actualizing } \\
\text { person strives to be at the top of his/her business or, } \\
\text { in any case, as good as he/she can. }\end{array}$ & $\begin{array}{l}\text { Formation of motivations for achievements. } \\
\text { Identification of areas of activity in which a } \\
\text { child is most successful, and constant } \\
\text { support of their values. }\end{array}$ \\
\hline $\begin{array}{l}\text { Achieving the peak of experiences. } \\
\text { "The Peak of experience" resembles an insight. } \\
\text { These are the moments when we become deeply } \\
\text { involved, excited and connected with the world. } \\
\text { Achieving the peak of experience is a fundamental } \\
\text { change in attitude towards the world, the emergence } \\
\text { of a new point of view. }\end{array}$ & $\begin{array}{l}\text { Creation of educational situations in which } \\
\text { likely and learning how to "recognize" them. }\end{array}$ \\
\hline $\begin{array}{l}\text { Revealing unproductive psychological defenses } \\
\text { "highlighting psychopathology") and rejecting } \\
\text { them. }\end{array}$ & $\begin{array}{l}\text { Identification and removal of mental } \\
\text { stumbling blocks that impede search } \\
\text { (creative) activity. }\end{array}$ \\
\hline
\end{tabular}

\section{Conclusiones}

Speaking of the consultant's task as helping the client to live the moments of selfactualization, A. Maslow writes that "We need to develop a new way of communication. (...) this way is largely (than the one to which we are accustomed, watching teachers to write on the board) worthy being a model to train, counsel, help adults (and children, in particular - I.A.) in developing at their full capacity" (Maslow, 2002, p.11).

These ideas are completely relevant for modern pedagogical practice, first of all, that which is aimed at the development of an individual as the subject of creativity of self-actualization.

The implementation of a humanistic pedagogical process aimed at facilitating the learner's personal growth requires fundamental scientific and methodological support, which encompasses: methodology and technology for organizing the educational process as a facilitative interaction between its participants; methodology and training methodology of the facilitator teacher.

The development of such support constitutes the prospects of development of facilitative pedagogy. 
The conducted study allows us to make the following conclusion:

1) The focus of Russian education on the introduction of new approaches requires a rethinking of existing approaches and principles.

2) An orientation towards personal developmental learning based on pedagogical interaction is becoming the key principle of the new educational system.

3) The psychological and pedagogical process is aimed at creating conditions that ensure the development of a creative personality, capable of independent research, cognitive and practical activities. A special role in education belongs to a teacher who acts as a facilitator, stimulates the process of mental activity in the educational process.

4) Facilitative pedagogy - the field of pedagogy and educational psychology, associated with the implementation of a personality-developing educational paradigm. The key categories of facilitative pedagogy are subjectivity associated with the active-emotional inclusion of its participants in the educational process - the teacher and students.

5) The subjective category included in the educational process is the creativity of selfactualization. Personal freedom as a criterion and guarantee of success in educational activities plays a significant role in the implementation of creative potential.

6) The social situation of development plays a key role in the development of a creative personality. Facilitative pedagogy recognizes the influence on the formation of individuality of the social situation of development. Subject-subject interaction proceeds from the recognition of teachers and students as equal participants in communication.

\section{References}

Amonashvili, Sh.A. (1990) Personal-humane basis of the pedagogical process. Minsk, Belarus, 560

Andreev, V.I. (1988) Dialectics of a creative person education and self-education. Kazan, Russia, 228

Avdeyeva, I.N. \& Adonina, L.V. (2016) Psychological and Organizational Prerequisites for the Successful Professional Development of a Facilitator Teacher. Traditions and Innovations in the Study and Teaching of Philological Disciplines at University and School: Collective Monograph. Moscow, Russia, 3-20

Avdeyeva, I.N. (2013) The Meaning of Settings of a Facilitator Teacher: the Basic Content and the Ways of Formation. The World of Psychology. Issue 3, 177-190

Bakhtin, M.M. (1984-1985) To the philosophy of an act. Philosophy and sociology of science and technology. Yearbook, 80-160

Bakshaeva, Kh.A. \& Verbitskii A.A. (2006) Psychology of student motivation: textbook. Moscow, Russia, 184

Ball, G.A. (1997) The Psychological Content of Personal Freedom: Essence and Constituent Parts. Psychological Journal. Issue 5, 7-19

Berdyaev, N.A. (1993) About a person's purpose, Moscow, Russia, 320

Bogoyavlenskaya, D.B. (1999) "Subject of activity" in the problems of creativity. Issues of psychology. No. 2, 35-42

Borisova, L.N. (1999) Pedagogical conditions for the development of professional reflection of students of a pedagogical college: author's abstract, Cand. Pedagogy. Kursk, Russia, 16

Bystrova, A.N. (2002) The World of Culture (Fundamentals of Cultural Studies). Novosibirsk, Russia, 712

Clarin, M.V. (2020) Corporate training from "A" to "Z": a scientific and practical manual, Moscow, Russia, 224

Dimova, O.I. (2002) Pedagogical conditions for the development of faculty interaction ability in future teachers: author's abstract, Cand. Pedagogy: 13.00.01 Khabarovsk, Russia, 199

Dobrogaeva I.V. \& others. Diagnosis and treatment of neurosis among children and adolescents: Methodological recommendations. Kharkov, Ukraine, 18

Druzhinin V.N. Psychology of general abilities. Saint-Petersburg, Russia, 368

Ermolaev-Tomina, L.B. (1990) The study of factors determining individual differences in creative 
activity manifestation: From the coll. "Psychology of creativit. Moscow, Russia, 130

Gazman, O.S. (2000) The pedagogy of freedom: the path to the humanistic civilization of the XXI-st century. Homeroom teacher, No. 3, 6-33

Grigorieva, A.N. (2004) Formation of the humanistic orientation of the future teacher at pedagogical college: author's abstract, Cand. Pedagogy, Pskov, Russia, 199

Karpenko N. (1997) Fear: a positive and negative role in child development. Preschool Vihovannya, No12, 18-19

Kodzhaspirov, A.Iu. (2009) Diagnostics of the psychological safety of the educational environment: a methodological guide. Moscow, Russia, 116

Kulikova, L.N. (2001) Educate yourself. Humanization of education and personal self-development. Khabarovsk, Russia, 333

Leontiev, D.A. (2011) New guidelines for personality understanding in psychology: from necessary to possible. Psychology Issues, No. 11, 3-27

Markova A.K. (1996) Psychology of professionalism, Moscow, Russia, 308

Markova I.N. (2008) The role of the cultural and educational environment in the socialization of foreign students // Secondary vocational education. No. 3, 7-8

Maslow, A. (2002) Personal Self-Actualization and Education. Translated from English into Russian by G.A. Ball. Kiev-Donetsk, Ukraine, 52

Matyunin, V.G. (1994) Unconventional pedagogy. Moscow, Russia, 96

Molyako, V.A. (1983) Psychology of creative task solution by schoolchildren. Kiev, Ukraine, 96

Osnitsky, A.K.(1996) The Problems of the Study of Subjective Activity. Psychology. Issues 1, 519

Ovcharova P.B. (2007) Practical facilitation of the work of a school teacher, Moscow, Russia, 464

Panov V.I. \& Gerasimova T.Iu. (2006) Mental states of a schoolchild in a tense educational environment // Bulletin of the Samara Academy of Humanities. Psychology. No. 2 (5), 3-19

Peseshkian, N. (1995) Psychotherapy for every day. Moscow, Russia, 327

Psychology of creativity / Ed. by Ya.A. Ponomarev. Moscow, Russia, 224

Rogers, C. \& Freiberg, J. (2002) Freedom to Learn. Moscow, Russia, 527

Rogers, K. (2002) Client-centered psychotherapy. Translation from English by T. Rozhkova, Yu. Ovchinnikova, G. Pilyuchkina, Moscow, Russia, 512

Romashina, S.Ia. \& Maier, A.A. (2010) Pedagogical facilitation: essence and ways of implementation in education. Moscow, Russia, 160

Savenkov, A.I. (2008) Educational environment. School psychologist, 19-20

Scheblanova, E.I. (2018) Features of cognitive and motivational-personal development of gifted high school students. Psychology Issues, No. 6, 35-47

Slastenin, V.A., Podymova, L.S. (1997) Pedagogy: Innovation. IPE "Publishing House Magister", 224

Stepanov, S.G. (2002) Improving the facilitation competence of teachers as a precondition for the dignity of high school students: author's abstract, Cand. Pedagogy, Khabarovsk, Russia, 23

Vachkov, I.V. \& Deriabo S.D. (2000) Windows to the world of training: methodological foundations of the subjective approach to group work, Moscow, Russia, 271

Zakharov, A.I. (2020) The origin of childhood neurosis and psychotherapy. Moscow, Russia, 448

Zhizhina, I.V. (2000) Psychological features of teacher facilitation development: author's abstract, Psychology. Ekaterinburg, Russia, 153

Financing: The study was financially supported by the Federal State Autonomous Educational Institution of Higher Education "Sevastopol State University" (Project 48/06-31 of 04/06/2020 "Methodology and Methods for the Use of Information and Communication Technologies in the Preparation and Furtherance of the Professional Activities of Facilitator Teachers") 